\title{
Revitalisasi Danau Limboto dengan Pengerukan Endapan di Danau: Pemodelan, Analisis, dan Simulasinya
}

\author{
Sri Lestari Mahmud ${ }^{1,}$, Novianita Achmad ${ }^{2}$, Hasan S. Panigoro $^{3}$ \\ 1,2,3 Jurusan Matematika, Universitas Negeri Gorontalo, Gorontalo 96128, Indonesia \\ *Corresponding author: sri.lestari@ung.ac.id
}

\begin{abstract}
Abstrak
Danau Limboto merupakan salah satu aset Provinsi Gorontalo yang memberikan banyak manfaat bagi masyarakat sekitar. Masalah utama yang dihadapi yaitu terjadinya pendangkalan danau Limboto akibat sedimentasi yang disebabkan oleh erosi hutan, limbah rumah tangga, eceng gondok, dan pembudidayaan ikan yang tidak ramah lingkungan. Pada artikel ini, dilakukan pendekatan matematis untuk memodelkan masalah pendangkalan danau Limboto dengan memasukkan unsur revitalisasi berupa pengerukan pada danau. Pemodelan diawali dengan membangun dan membatasi asumsi, mengkonstruksi variabel dan parameter dalam simbol matematika, dan membentuknya menjadi sebuah sistem persamaan diferensial orde satu secara deterministik. Analisis dilanjutkan dengan mempelajari dinamika dari model berupa mengidentifikasi eksistensi titik kesetimbangan dan kondisi kestabilannya. Selanjutnya diberikan simulasi numerik untuk memperlihatkan kondisi pendangkalan berdasarkan kondisi kestabilan yang diperoleh sebelumnya.
\end{abstract}

Kata Kunci: Danau Limboto; Pendangkalan; Revitalisasi; Pemodelan; Dinamika

\begin{abstract}
Limboto lake is one of assets of Province of Gorontalo that provides many benefits to the surrounding society. The main problem of Limboto lake is the silting of the lake due to sedimentation caused by forest erosion, household waste, water hyacinth, and fish farming which is not environmentally friendly. In this article, a mathematical approach is used to modeling the Limboto lake siltation by including the revitalization solution namely the lake dredging. Mathematical modeling begins by building and limiting assumptions, constructing variables and parameters in mathematical symbols, and forming them into a first order differential equation system deterministically. Furthermore, we study the dynamics of the model such as identifying the existence of equilibrium points and their stability conditions. We also give a numerical simulations to show the conditions based on the stability requirements in previous analytical results.
\end{abstract}

Keywords: Limboto Lake; Siltation; Revitalization; Modeling; Dinamics

\section{Pendahuluan}

Danau adalah salah satu bentuk sumberdaya yang dikaruniakan oleh Sang Pencipta untuk menunjang kehidupan seluruh mahluk hidup di bumi ini, termasuk manusia. Oleh karenanya, suatu kewajiban bagi kita semua untuk menjaga eksistensi danau beserta segala potensi yang ada di dalamnya sebagai salah satu usaha untuk menjamin kelangsungan hidup generasi kini dan mendatang. Salah satu danau yang banyak memberikan manfaat bagi masyarakatnya adalah danau Limboto yang terletak di Provinsi Gorontalo. Danau Limboto berfungsi sebagai penyedia air bersih, habitat tumbuhan dan satwa, pengatur fungsi hidrologi, pencegah bencana alam, stabilisasi sistem dan proses-proses alam, penghasil sumberdaya alam hayati, penghasil energi, sarana transportasi, rekreasi dan olahraga, sumber perikanan (baik budidaya maupun perikanan tangkap), sumber pendapatan, pengendali banjir, dan sebagai sarana penelitian dan pendidikan. Selain itu, danau Limboto juga berfungsi sebagai sumber mata pencaharian penduduk Gorontalo umumnya khususnya masyarakat sekitarnya.

Danau Limboto kini berada pada kondisi yang sangat memperihatinkan karena mengalami proses penyusutan dan pendangkalan yang mengancam keberadaannya dimasa yang akan datang [1]. Berdasarkan data yang diperoleh dari BALIHRISTI bahwa pada tahun 1932 rata-rata kedalaman Danau Limboto 30 meter dengan luas $7.000 \mathrm{Ha}$, dan tahun 1961 rata-rata kedalaman danau berkurang menjadi 10 meter dan luas menjadi 4.250 Ha. Sedangkan tahun 1990 - 2008 kedalaman Danau Limboto rata-rata tinggal 2,5 meter dengan luas 3.000 Ha. Semakin berkurangnya luasan perairan danau menyebabkan semakin menurunnya fungsi danau sebagai kawasan penampung air dan tempat hidup biota perairan sehingga berpotensi terjadinya banjir dan hilangnya organisme endemik yang ada di Danau Limboto [2]. 
Pendangkalan Danau Limboto terutama diakibatkan oleh adanya erosi dan sedimentasi akibat usaha-usaha pertanian yang tidak mengindahkan konservasi tanah dan kegiatan pembukaan hutan (illegal logging) di daerah hulu sungai (tangkapan air) terutama pada DAS Limboto [3]. Selain itu, pendangkalan juga terjadi karena adanya pembudidayaan ikan yang tidak ramah lingkungan [4] dan perkembangan populasi tumbuhan air (eceng gondok) yang tidak terkendali di danau [5, 6], yang menyebabkan pengurangan daya tampung air di danau serta menyebabkan kehilangan air, karena proses evapotranspirasi yang berlebihan [7].

Melihat kondisi danau Limboto yang sudah sangat memprihatinkan ini, maka penulis berinisiatif memodelkan faktor-faktor penyebab pendangkalan danau Limboto secara matematik. Pemodelan matematika merupakan salah satu teknik untuk merepresentasikan suatu sistem yang kompleks ke dalam model matematika. Dengan kata lain, pemodelan matematika merupakan proses membangun suatu model matematika yang dapat merepresentasikan suatu permasalahan kompleks yang sedang diamati [8]. Dengan adanya pemodelan ini diharapkan dapat meberikan sebuah solusi yang dapat membuat pendangkalan danau tidak akan terjadi lagi pada masa mendatang. Atau dengan kata lain, solusi ini dapat membuat volume endapan yang ada di danau limboto tidak akan bertambah.

\section{Metode}

Berikut ini tahapan yang dilakukan untuk mempelajari pendangkalan danau Limboto dengan menggunakan pemodelan matematika.

1. Merumuskan variabel-variabel yang berhubungan dengan pendangkalan danau Limboto.

2. merumuskan asumsi-asumsi dan menerjemahkannya dalam bahasa matematika.

3. Menetapkan dan membatasi parameter-parameter yang memberikan perubahan terhadap variabel-varibel yang ada.

4. Mengkonstruksi model matematika pendangkalan danau Limboto dalam suatu sistem persamaan diferensial orde satu.

5. Mempelajari dinamika dari model dengan mengidentifikasi eksistensi titik kesetimbangan dan kestabilannya.

6. Memberikan simulasi numerik untuk memberikan interpretasi geometris terhadap hasil analisis dinamik yang dilakukan dengan menggunakan skema numerik Runge-Kutta orde-4.

\section{Hasil dan Pembahasan}

\subsection{Formulasi Model}

Langkah awal yang dilakukan dalam memodelkan pendangkalan danau limboto, terlebih dahulu dilakukan identifikasi dan pembatasan terhadap variabel dan parameternya. Faktor-faktor yang menyebabkan pendangkalan danau Limboto sangatlah kompleks. Untuk mempersempit dimensi dari model, diidentifikasi faktor-faktor yang diasumsikan memberikan pengaruh terbesar terhadap pendangkalan danau Limboto. Faktor-faktor ini disebut dengan variabel yang besarannya bergantung pada waktu. Oleh karena itu, faktor-faktor ini disebut dengan variabel terikat, sedangkan waktu disebut dengan variabel bebas, yang disimbolkan secara matematis seperti pada Tabel 1.

Tabel 1. Faktor-faktor yang mempengaruhi pendangkalan danau Limboto dan penyimbolannya

\begin{tabular}{clc}
\hline Variabel & Interpretasi & Besaran (contoh satuan) \\
\hline$x(t)$ & kepadatan populasi eceng gondok pada & volume $\left(\mathrm{m}^{3}\right)$ \\
$y(t)$ & waktu $t$ & volume $\left(\mathrm{m}^{3}\right)$ \\
$u(t)$ & jumlah nutrien di danau pada waktu $t$ & volume $\left(\mathrm{m}^{3}\right)$ \\
$v(t)$ & jumlah endapan di danau pada waktu $t$ & volume $\left(\mathrm{m}^{3}\right)$ \\
$t$ & volume danau pada waktu $t$ & detik, menit, tahun, dan sebagainya \\
\hline
\end{tabular}

Selanjutnya diidentifikasi penyebab berubahnya nilai dari variabel yang didefinisikan pada Tabel 1 ketika terjadi perubahan waktu, yang disebut dengan parameter dari model. Parameter ini juga dibatasi pada beberapa hal yang dianggap memberikan pengaruh terbesar, sehingga secara matematis dapat menghindari model matematika yang lebih kompleks. Adapun parameter yang dipilih disajikan pada Tabel 2.

Setelah mendefinisikan variabel dan parameter, dirumuskan kondisi untuk setiap laju perubahan variabel-variabel terikatnya sebagai berikut.

1. Laju perubahan kepadatan populasi eceng gondok di danau Limboto. 
Tabel 2. Deskripsi parameter pada model pendangkalan danau Limboto

\begin{tabular}{|c|c|c|}
\hline Parameter & Interpretasi & satuan \\
\hline$r$ & laju pertumbuhan intrinsik eceng gondok & $\% /$ hari \\
\hline$\alpha$ & konstanta daya dukung lingkungan eceng gondok oleh volume danau & $\%$ \\
\hline$\beta$ & konstanta daya dukung lingkungan eceng gondok oleh nutrien & $\%$ \\
\hline$\omega$ & proteksi lingkungan (makanan lain) & $m^{3}$ \\
\hline$\kappa_{1}$ & konsentrasi nutrien yang dibawa oleh sungai akibat limbah rumah tangga & $\%$ \\
\hline$\kappa_{2}$ & konsentrasi nutrien dibawa oleh sungai dari erosi akibat penebangan hutan & $\%$ \\
\hline$\kappa_{3}$ & konsentrasi nutrien dibawa oleh sungai dari areal persawahan & $\%$ \\
\hline$\sigma$ & laju air sungai ke danau & $m^{3} /$ hari \\
\hline$\delta$ & laju air danau ke laut melalui sungai & $m^{3} /$ hari \\
\hline$\eta$ & konsentrasi nutrien di danau akibat pembudidayaan ikan yang tidak ramah lingkungan & $\% / h a r i$ \\
\hline$\tilde{\zeta}$ & konsentrasi nutrien yang diserap oleh eceng gondok & $\% /$ hari \\
\hline$\zeta_{1}$ & konsentrasi endapan yang dibawa oleh sungai akibat limbah rumah tangga & $\%$ \\
\hline$\zeta_{2}$ & konsentrasi endapan yang dibawa oleh sungai dari erosi akibat penebangan hutan & $\%$ \\
\hline$\zeta_{3}$ & konsentrasi endapan yang dibawa oleh sungai dari areal persawahan & $\%$ \\
\hline$\Lambda$ & laju pengerukan danau & $m^{3} /$ hari \\
\hline$\gamma$ & laju pertambahan endapan di danau akibat kematian dari eceng gondok & $\% / h a r i$ \\
\hline
\end{tabular}

Untuk mengkonstruksi laju perubahan kepadatan populasi eceng gondok, digunakan model logistik yang dikembangkan oleh Verhulst pada tahun 1838 [9-11]. Model ini dimodifikasi dengan mengasumsikan bahwa eceng gondok tumbuh secara logistik dengan daya dukungnya adalah jumlah nutrien yang tersedia, volume danau, dan proteksi lingkungan yang diterimanya. Dengan demikian diperoleh persamaan sebagai berikut.

$$
\frac{d x}{d t}=r x\left(1-\frac{x}{\alpha y+\beta v+\omega}\right)
$$

2. Laju perubahan jumlah nutrien di danau Limboto.

Laju perubahan jumlah nutrien dikonstruksi dengan memperhitungkan jumlah nutrien yang dibawa oleh air sungai ke danau, jumlah nutrien yang dibawa oleh sungai dari air danau ke laut, jumlah nutrien yang dihasilkan dari pembudidayaan ikan yang tidak ramah lingkungan, dan jumlah nutrien yang diserap oleh eceng gondok. Asumsi ini dirumuskan sebagai berikut.

Laju perubahan jumlah nutrien di danau $=$ laju nutrien yang masuk ke danau melalui sungai

- laju nutrien yang keluar dari danau ke laut

+ laju pertambahan nutrien yang berasal dari pembudidayaan ikan yang tidak ramah lingkungan

- laju penyerapan nutrien oleh eceng gondok

Berdasarkan rumusan di atas, dapat dikonstruksi diagram transfer sebagai berikut.

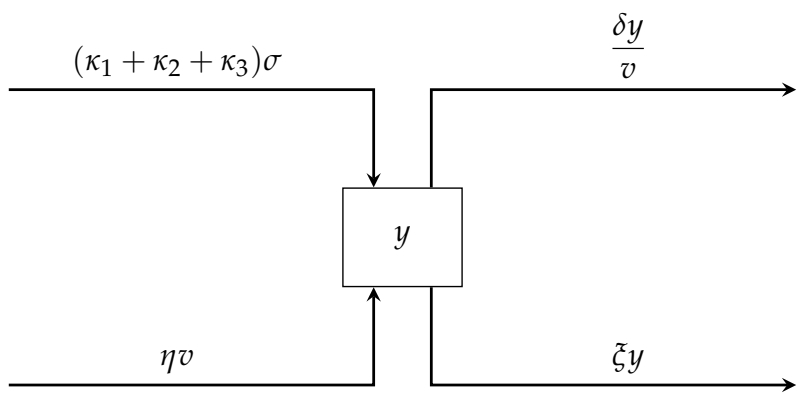

Gambar 1. Digram transfer laju perubahan jumlah nutrien di danau Limboto

Dengan demikian, diperoleh persamaan diferensial untuk laju perubahan jumlah nutrien yaitu:

$$
\frac{d y}{d t}=\left(\kappa_{1}+\kappa_{2}+\kappa_{3}\right) \sigma-\frac{\delta y}{v}+\eta v-\xi y
$$

3. Laju perubahan jumlah endapan di danau Limboto.

Laju perubahan jumlah endapan hampir mirip dengan laju pertambahan nutrien di danau sehingga dapat dirumuskan persamaan sebagai berikut. 
Laju perubahan jumlah endapan di danau $=$

laju endapan yang masuk ke danau melalui sungai - laju endapan yang keluar dari danau ke laut

Rumusan ini dapat dideskripsikan dalam diagram transfer sebagai berikut.

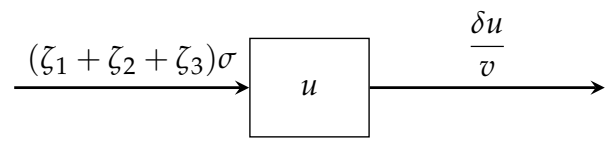

Gambar 2. Digram transfer laju perubahan jumlah endapan di danau Limboto

Berdasarkan Gambar 2, diperoleh persamaan diferensial sebagai berikut.

$$
\frac{d u}{d t}=\left(\zeta_{1}+\zeta_{2}+\zeta_{3}\right) \sigma-\frac{\delta u}{v}
$$

4. Laju perubahan volume danau Limboto.

Laju perubahan volume danau bergantung pada laju konversi eceng gondok yang mati mejadi endapan, dan penyatuan endapan di air dengan dasar danau. Selain itu, dengan adanya revitalisasi berupa pengerukan danau, volume danau bisa bertambah. Asumsi ini dapat dituliskan dalam persamaan matematika berikut.

Laju perubahan volume danau $=\quad$ Laju pengerukan danau

- laju penyatuan endapan dengan dasar danau

- laju konversi eceng gondok yang mati menjadi endapan

Rumusan tersebut dapat digambarkan dalam diagram transfer seperti pada Gambar 3.

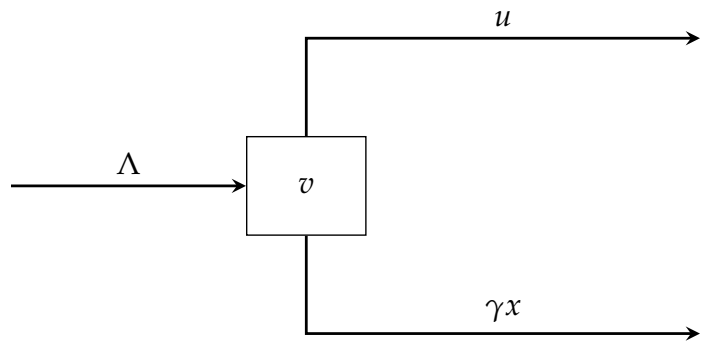

Gambar 3. Digram transfer laju perubahan jumlah endapan di danau Limboto

Dengan melihat Gambar 3, diperoleh persamaan diferensial sebagai berikut.

$$
\frac{d v}{d t}=\Lambda-u-\gamma x
$$

Berdasarkan pers. (1), (2), (3), dan (4), diperoleh model pendangkalan danau Limboto dengan dengan revitalisasi berupa pengerukan danau yang didefinisikan oleh sistem persamaan diferensial yaitu

$$
\begin{aligned}
& \frac{d x}{d t}=r x\left(1-\frac{x}{\alpha y+\beta v+\omega}\right) \\
& \frac{d y}{d t}=\left(\kappa_{1}+\kappa_{2}+\kappa_{3}\right) \sigma-\frac{\delta y}{v}+\eta v-\xi y \\
& \frac{d u}{d t}=\left(\zeta_{1}+\zeta_{2}+\zeta_{3}\right) \sigma-\frac{\delta u}{v} \\
& \frac{d v}{d t}=\Lambda-u-\gamma x
\end{aligned}
$$

Selanjutnya akan dipelajari dinamika dari model (5) yaitu dengan melakukan identifikasi terhadap eksistensi dan kestabilan titik kesetimbangan. Tujuannya untuk mempelajari kondisi yang dibutuhkan agar eksistensi dari danau Limboto tetap terjaga, dan melihat besar usaha yang dibutuhkan dari pengerukan danau, sehingga endapan yang ada tidak akan mengakibatkan volume danau berkurang. 


\subsection{Eksistensi Titik Kesetimbangan}

Titik kesetimbangan model (5) diperoleh dengan menyelesaikan sistem persamaan berikut.

$$
\begin{aligned}
r x\left(1-\frac{x}{\alpha y+\beta v+\omega}\right) & =0, \\
\left(\kappa_{1}+\kappa_{2}+\kappa_{3}\right) \sigma-\frac{\delta y}{v}+\eta v-\xi y & =0, \\
\left(\zeta_{1}+\zeta_{2}+\zeta_{3}\right) \sigma-\frac{\delta u}{v} & =0, \\
\Lambda-u-\gamma x & =0 .
\end{aligned}
$$

dari persamaan pertama di pers. (6), diperoleh $x=0$ atau $x=\alpha y+\beta v+\omega$. Jika $x=0$ maka diperoleh titik kesetimbangan:

$$
E_{1}=\left(0, \frac{\left(\kappa_{1}+\kappa_{2}+\kappa_{3}\right) \sigma \bar{v}+\eta \bar{v}^{2}}{\delta+\xi \bar{v}}, \Lambda, \bar{v}\right),
$$

dengan $\bar{v}=\frac{\delta \Lambda}{\left(\zeta_{1}+\zeta_{2}+\zeta_{3}\right) \sigma}$. Titik kesetimbangan $E_{1}$ merupakan titik kesetimbangan bebas eceng. Jelas bahwa $E_{1} \in \mathbb{R}_{+}^{4}$. Selanjutnya untuk $x=\alpha y+\beta v+\omega$, didapatkan titik kesetimbangan:

$$
E_{2}=\left(x^{*}, y^{*}, u^{*}, v^{*}\right),
$$

dimana

$$
\begin{aligned}
x^{*} & =\frac{1}{\gamma}\left(\Lambda-\frac{\left(\zeta_{1}+\zeta_{2}+\zeta_{3}\right) \sigma v^{*}}{\delta}\right), \\
y^{*} & =\frac{\Lambda}{\alpha \gamma}-\frac{1}{\alpha}\left(\frac{\left(\zeta_{1}+\zeta_{2}+\zeta_{3}\right) \sigma v^{*}}{\delta \gamma}+\beta v^{*}+\omega\right), \\
u^{*} & =\frac{\left(\zeta_{1}+\zeta_{2}+\zeta_{3}\right) \sigma v^{*}}{\delta},
\end{aligned}
$$

dan $v^{*}$ adalah solusi positif dalam $v$ dari polinom $a_{1} v^{2}-a_{2} v+a_{3}=0$ dengan

$$
\begin{aligned}
& a_{1}=\eta+\frac{\left(\zeta_{1}+\zeta_{2}+\zeta_{3}\right) \sigma \xi}{\alpha \delta \gamma}+\frac{\beta \xi}{\alpha} \\
& a_{2}=\frac{\xi \Lambda}{\alpha \gamma}-\left(\left(\kappa_{1}+\kappa_{2}+\kappa_{3}\right) \sigma+\frac{\left(\zeta_{1}+\zeta_{2}+\zeta_{3}\right) \sigma}{\alpha \gamma}+\frac{\beta \delta}{\alpha}+\frac{\omega \xi}{\alpha}\right) \\
& a_{3}=\frac{\delta \omega}{\alpha}-\frac{\delta \Lambda}{\alpha \gamma} .
\end{aligned}
$$

Perhatikan bahwa jika $y^{*}=0$ mengakibatkan titik kesetimbangan interior tidak eksis secara biologis. Oleh karena itu diasumsikan $y^{*}>0$ atau $\Lambda>\frac{\left(\zeta_{1}+\zeta_{2}+\zeta_{3}\right) \sigma v^{*}}{\delta}+\beta \gamma v^{*}+\omega \gamma$. Titik kesetimbangan $E_{2}$ disebut dengan titik kesetimbangan interior dimana seluruh variabel eksis secara biologis dengan syarat eksistensinya ditunjukkan oleh teorema berikut.

Teorema 1. Misalkan $\Lambda>\max \left\{\frac{\left(\zeta_{1}+\zeta_{2}+\zeta_{3}\right) \sigma v^{*}}{\delta}+\beta \gamma v^{*}+\omega \gamma, \frac{\left(\kappa_{1}+\kappa_{2}+\kappa_{3}\right) \alpha \gamma \sigma}{\xi}+\frac{\left(\zeta_{1}+\zeta_{2}+\zeta_{3}\right) \sigma}{\xi}+\frac{\beta \delta \gamma}{\xi}+\omega \gamma\right\}$.

(i) Jika $a_{2}^{2}<4 a_{1} a_{3}$ maka tidak ada titik kesetimbangan di interior dari model (5).

(ii) Jika $a_{2}^{2} \geq 4 a_{1} a_{3}$ maka ada satu titik kesetimbangan di interior dari model (5).

bukti. $\Lambda>\max \left\{\frac{\left(\zeta_{1}+\zeta_{2}+\zeta_{3}\right) \sigma v^{*}}{\delta}+\beta \gamma v^{*}+\omega \gamma, \frac{\left(\kappa_{1}+\kappa_{2}+\kappa_{3}\right) \alpha \gamma \sigma}{\xi}+\frac{\left(\zeta_{1}+\zeta_{2}+\zeta_{3}\right) \sigma}{\xi}+\frac{\beta \delta \gamma}{\xi}+\omega \gamma\right\}$ mengakibatkan $x^{*}>0$, $y^{*}>0$, dan $a_{2}>0$. Perhatikan juga bahwa $u^{*}$ dan $a_{1}$ selalu positif. Dengan demikian, eksistensi dari $E_{2}$ bergantung dari nilai $v^{*}$. Karena $v^{*}$ adalah solusi positif dari polinom $a_{1} v^{2}-a_{2} v+a_{3}=0$ maka diperoleh:

$$
v_{1}^{*}=\frac{a_{2}+\sqrt{a_{2}^{2}-4 a_{1} a_{3}}}{2}, \quad v_{2}^{*}=\frac{a_{2}-\sqrt{a_{2}^{2}-4 a_{1} a_{3}}}{2} .
$$


Jika $a_{2}^{2}<4 a_{1} a_{3}$ maka $v_{1,2}^{*} \in \mathbb{C}$ sehingga $E_{2} \notin \mathbb{R}^{4}$. Dengan demikian tidak ada titik kesetimbangan di interior dari model (5). Jika $a_{2}^{2}=4 a_{1} a_{3}$ maka diperoleh $v^{*}=\frac{a_{2}}{2}$. Karena $a_{2}>0$ maka $v^{*}>0$ sehingga hanya ada satu titik kesetimbangan di interior. Jika $a_{2}^{2}>4 a_{1} a_{3}$ maka $v_{1,2}^{*} \in \mathbb{R}$. Sangat jelas bahwa $v_{1}^{*}=\frac{a_{2}+\sqrt{a_{2}^{2}-4 a_{1} a_{3}}}{2}>0$. Untuk $v_{2}^{*}=\frac{a_{2}-\sqrt{a_{2}^{2}-4 a_{1} a_{3}}}{2}$, titik kesetimbangan ini ada jika $a_{2}>\sqrt{a_{2}^{2}-4 a_{1} a_{3}}$. Karena $\Lambda>\omega \gamma$ maka $a_{3}<0$ yang berakibat $a_{2}<\sqrt{a_{2}^{2}-4 a_{1} a_{3}}$ sehingga bertentangan dengan syarat eksistensi $v_{2}^{*}$. Oleh karena itu $v_{2}^{*}$ selalu bernilai negatif. Dengan demikian, hanya ada $v_{1}^{*}$ di interior.

Berdasarkan Teorema 1, eksistensi dari danau sangat bergantung pada laju pengerukan danau $(\Lambda)$. Untuk selanjutnya akan identifikasi syarat eksistensi danau dengan melihat kestabilan titik kesetimbangannya.

\subsection{Kestabilan Titik Kesetimbangan}

Kestabilan titik kesetimbangan dipelajari dengan melakukan pelinearan sehingga untuk kondisi awal yang cukup dekat dengan titik kesetimbangannya, solusi akan bergerak menuju ke titik kesetimbangan tersebut. Berdasarkan pelinearan, kita cukup mengidentifikasi nilai eigen dari matriks Jacobi model (5) di titik kesetimbangannya [12, 13]. Matriks Jacobi dari model (5) yaitu:

$$
J(x, y, u, v)=\left[\begin{array}{cccc}
r-\frac{2 r x}{\alpha y+\beta v+\omega} & \frac{\alpha r x^{2}}{(\alpha y+\beta v+\omega)^{2}} & 0 & \frac{\beta r x^{2}}{(\alpha y+\beta v+\omega)^{2}} \\
0 & -\frac{\delta}{v}-\xi & 0 & \frac{\delta y}{v^{2}}+\eta \\
0 & 0 & -\frac{\delta}{v} & \frac{\delta u}{v^{2}} \\
-\gamma & 0 & -1 & 0
\end{array}\right]
$$

Dengan memanfaatkan matriks Jacobi (9), dilakukan identifikasi terhadap kestabilan lokal titik kesetimbangan $E_{1}$ dan $E_{2}$ sebagai berikut.

Teorema 2. Titik kesetimbangan bebas eceng gondok $E_{1}=\left(0, \frac{\left(\kappa_{1}+\kappa_{2}+\kappa_{3}\right) \sigma \bar{v}+\eta \bar{v}^{2}}{\delta+\bar{\zeta} \bar{v}}, \Lambda, \bar{v}\right)$ selalu tidak stabil tipe pelana.

bukti. Dengan mengobservasi mariks Jacobi (9) di titik kesetimbangan $E_{1}$ diperoleh

$$
J(x, y, u, v)=\left[\begin{array}{cccc}
r & 0 & 0 & 0 \\
0 & -\frac{\delta}{\bar{v}}-\xi & 0 & \frac{\left(\kappa_{1}+\kappa_{2}+\kappa_{3}\right) \delta \sigma+\delta \eta \bar{v}}{\delta \bar{v}+\xi \bar{v}^{2}}+\eta \\
0 & 0 & -\frac{\delta}{\bar{v}} & \frac{\delta u}{\bar{v}^{2}} \\
-\gamma & 0 & -1 & 0
\end{array}\right],
$$

yang memberikan nilai eigen $\lambda_{1}=r, \lambda_{2}=\frac{\xi \bar{v}+\delta}{\bar{v}}$, dan $\lambda_{3,4}=-\frac{1}{2 \bar{v}}\left(\delta \pm \sqrt{\delta^{2}-4 \delta \Lambda}\right)$. Karena $\lambda_{1,2}>0$, $\operatorname{Re}\left(\lambda_{3,4}\right)<0$ jika $\delta<4 \Lambda$, dan $\lambda_{3,4}<0$ jika $\delta>4 \Lambda$, maka $E_{1}$ tidak stabil tipe pelana.

Teorema 3. Misalkan

$$
\begin{aligned}
& c_{1}=r+\xi+\frac{2 \delta}{v^{*}} \\
& c_{2}=(\beta \gamma+\xi) r+(2 r+\xi) \frac{\delta}{v^{*}}+\frac{\delta^{2}}{\left(v^{*}\right)^{2}}+\frac{\delta u^{*}}{\left(v^{*}\right)^{2}} \\
& c_{3}=(\alpha \eta+\beta \xi) \gamma r+(2 \beta \gamma+\xi) \frac{\delta r}{v^{*}}+\left(\alpha \gamma r y^{*}+\delta r+r u^{*}+u^{*} \xi\right) \frac{\delta}{\left(v^{*}\right)^{2}}+\frac{\delta^{2} u^{*}}{\left(v^{*}\right)^{3}}, \\
& c_{4}=(\alpha \eta+\beta \xi) \frac{\delta \gamma r}{v^{*}}+\left(\beta \delta \gamma+\xi u^{*}\right) \frac{\delta r}{\left(v^{*}\right)^{2}}+\left(\alpha \gamma y^{*}+u^{*}\right) \frac{\delta^{2} r}{\left(v^{*}\right)^{3}} .
\end{aligned}
$$

Titik kesetimbangan interior $E_{2}=\left(x^{*}, y^{*}, u^{*}, v^{*}\right)$ stabil asimtotik lokal jika $c_{1} c_{2} c_{3}>c_{3}^{2}+c_{1}^{2} c_{4}$. 


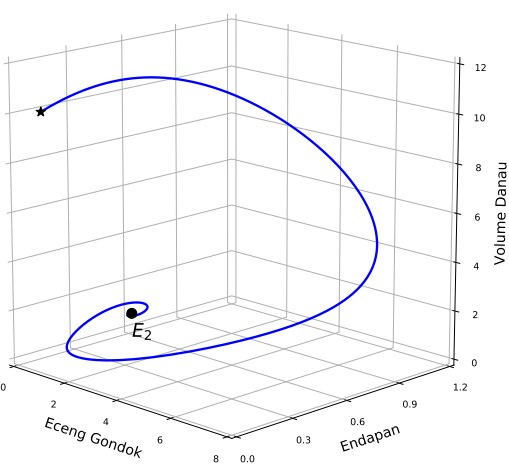

(a) Potret fase
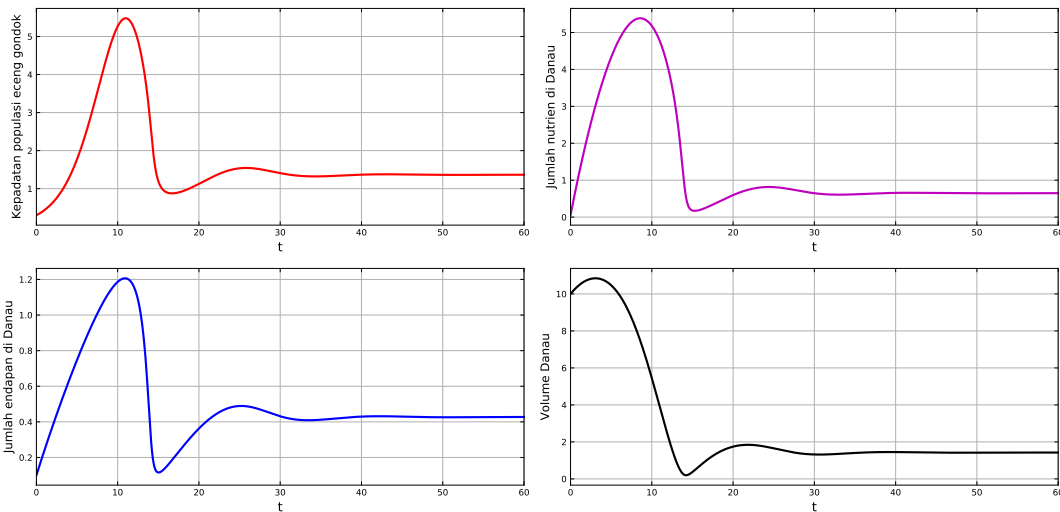

(b) Deret waktu

Gambar 4. Simulasi numerik dari model (5) dengan menggunakan nilai parameter (12)

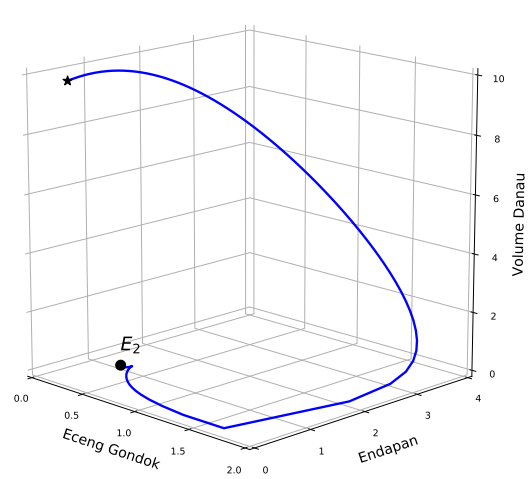

(a) Potret fase
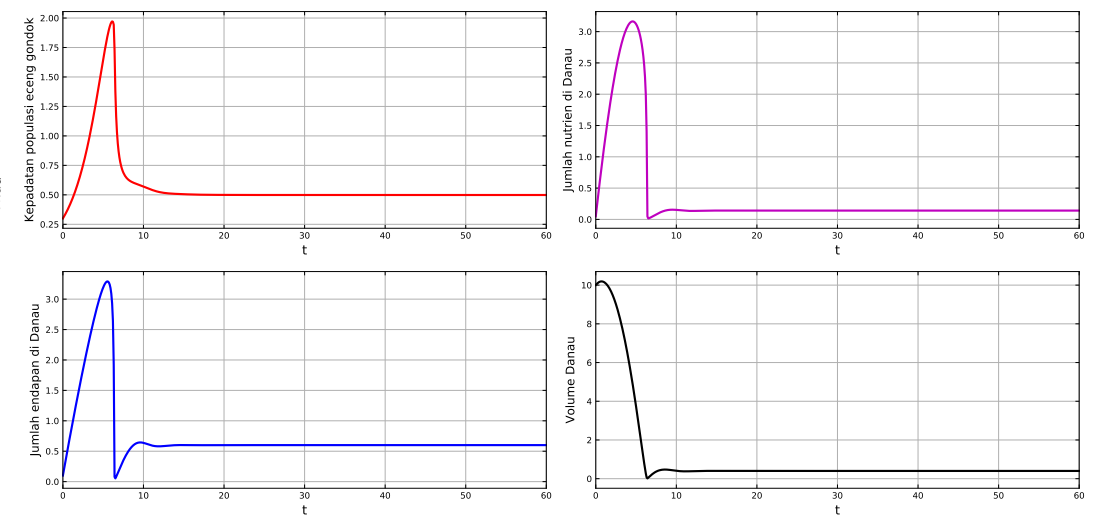

(b) Deret waktu

Gambar 5. Simulasi numerik dari model (5) dengan menggunakan nilai parameter (12) dan $\zeta_{1,2,3}=0.5$

bukti. Dengan melakukan subtitusi $E_{2}$ ke matriks Jacobi (9), diperoleh

$$
J(x, y, u, v)=\left[\begin{array}{cccc}
-r & \alpha r & 0 & \beta r \\
0 & -\left(\frac{\delta}{v^{*}}+\xi\right) & 0 & \frac{\delta y^{*}}{\left(v^{*}\right)^{2}}+\eta \\
0 & 0 & -\frac{\delta}{v^{*}} & \frac{\delta u^{*}}{\left(v^{*}\right)^{2}} \\
-\gamma & 0 & -1 & 0
\end{array}\right] .
$$

Matriks Jacobi (11) memiliki polinom karakterstik $\lambda^{4}+c_{1} \lambda^{3}+c_{2} \lambda^{2}+c_{3} \lambda+c_{4}=0$. Dengan menggunakan kriteria Routh-Hurwitz, $E_{2}$ stabil asimtotik lokal jika memenuhi $c_{1}>0, c_{3}>0, c_{4}>0$, dan $c_{1} c_{2} c_{3}>c_{3}^{2}+c_{1}^{2} c_{4}$ [8]. Karena $c_{i}>0$ untuk setiap $i=1,2,3,4$, maka $E_{2}$ stabil asimtotik lokal jika memenuhi $c_{1} c_{2} c_{3}>c_{3}^{2}+c_{1}^{2} c_{4}$.

Berdasarkan Teorema 2, populasi eceng gondok di danau Limboto tidak akan mungkin punah. Eksistensinya tetap terjaga sepanjang waktu. Secara biologis hal ini sangat masuk akal mengingat bahwa asupan nutrien selalu ada, baik dari limbah rumah tangga, area persawahan, dari erosi hutan, dan pembudidayaan ikan yang tidak ramah lingkungan. Oleh karena itu, kondisi yang diharapkan untuk menjaga agar tidak terjadi kepunahan danau Limboto yaitu dengan mengidentifikasi kondisi kesetimbangan $E_{2}$ dimana meskipun ada eceng gondok, tambak ikan, dan erosi hutan, volume danau dipertahankan dengan melakukan revitalisasi berupa pengerukan terhadap endapan yang ada. 


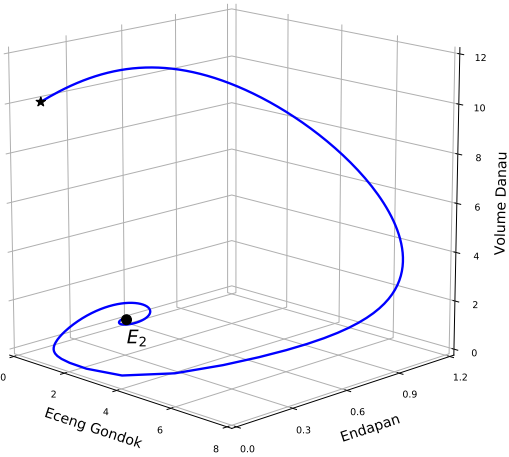

(a) Potret fase
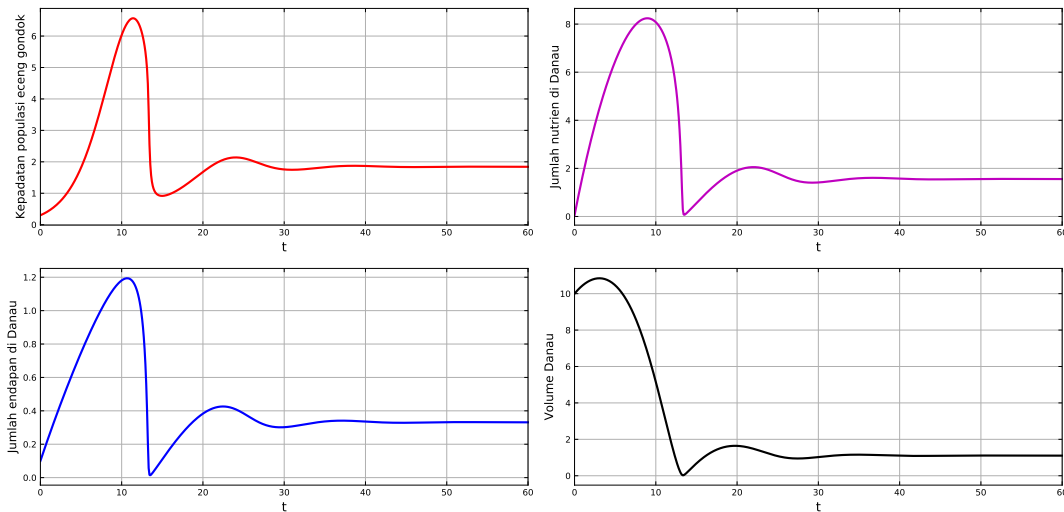

(b) Deret waktu

Gambar 6. Simulasi numerik dari model (5) dengan menggunakan nilai parameter (12) dan $\kappa_{1,2,3}=0.5$

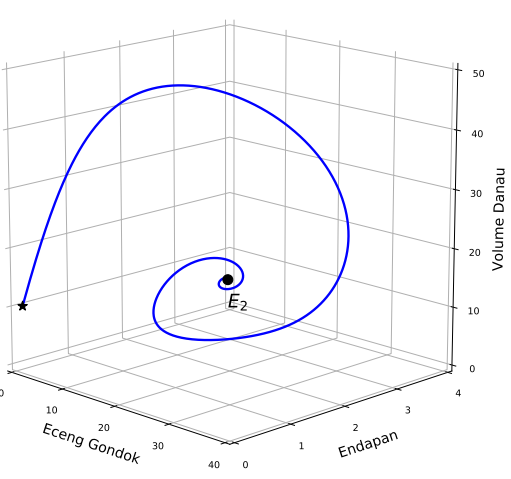

(a) Potret fase
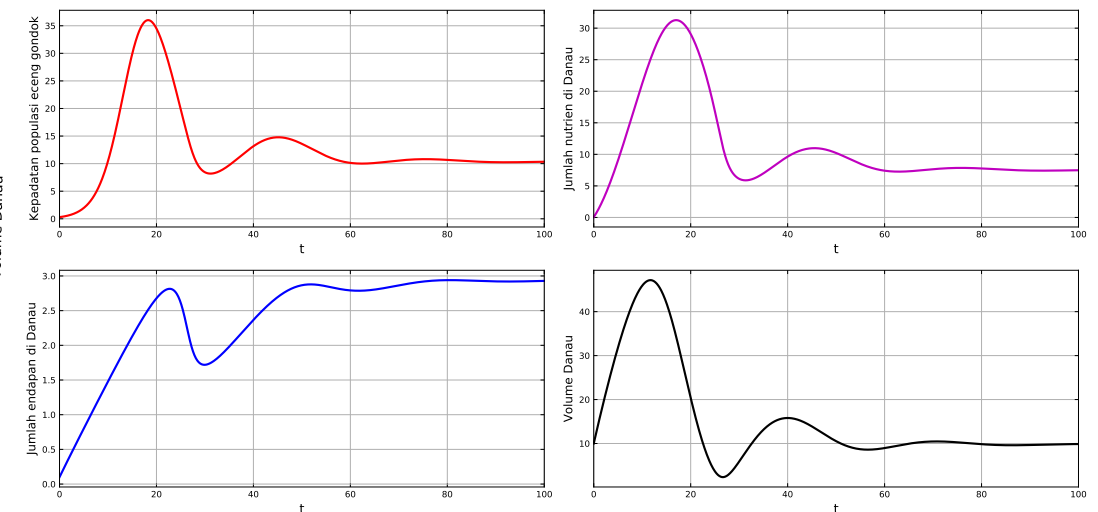

(b) Deret waktu

Gambar 7. Simulasi numerik dari model (5) dengan menggunakan nilai parameter (12) dan $\Lambda=5$

\subsection{Simulasi Numerik}

Tahapan ini dilakukan untuk memperlihatkan simulasi numerik dari model (5) berupa deret waktu dan potret fase. Karena tidak adanya data lapangan, pemilihan parameter disesuaikan dengan kondisi kestabilan yang diperoleh pada Teorema 3. Simulasi numerik dibagi mejadi dua bagian, yaitu dengan memperhatikan perubahan: (1) Jumlah endapan yang masuk ke danau; (2) Jumlah nutrien yang masuk ke danau, dan; (3) Besarnya laju pengerukan danau yang dilakukan. Untuk mengawali simulasi, ditetapkan nilai parameter sebagai berikut.

$$
\begin{array}{r}
r=0.4, \alpha=0.7, \beta=0.5, \omega=0.2, \kappa_{1}=\kappa_{2}=\kappa_{3}=0.1, \sigma=0.5 \\
\delta=0.5, \eta=0.1, \xi=0.1, \zeta_{1}=\zeta_{2}=\zeta_{3}=0.1, \Lambda=0.7, \gamma=0.2
\end{array}
$$

Pemilihan parameter (12) mengasumsikan bahwa laju air dari sungai ke danau dan dari danau ke laut sama. Selain itu, konsentrasi nutrien dan endapan dari limbah rumah tangga, areal persawahan, dan erosi hutan sama. Hal ini dilakukan agar mempermudah dalam proses simulasi. Pemilihan parameter juga didasarkan pada kestabilan yang ada di Teorema 3.

\section{Jumlah Endapan yang Masuk ke Danau}

Dengan menggunakan nilai parameter (12), diperoleh simulasi seperti pada Gambar 4, dimana seluruh variabel pada akhirnya konvergen ke $E_{2}$ sehingga meskipun ada endapan dan eceng gondok, eksistensi dari danau 
masih tetap bisa dipertahankan. Selanjutnya jumlah endapan yang masuk ke dalam danau ditingkatkan menjadi $\zeta_{1,2,3}=0.5$. Dapat dilihat pada Gambar 5, seluruh nilai variabel berkurang, dengan tingkat konvergensinya meningkat. Endapan yang ada di air berkurang karena telah mengeras dan menyatu dengan dasar danau. Jumlah eceng gondokpun berkurang karena daya dukungnya berupa nutrisi dan volume danau telah berkurang. Volume danau berkurang namun eksistensinya tetap terjaga meskipun dengan ukuran yang lebih kecil dari sebelumnya.

\section{Jumlah Nutrien yang Masuk ke Danau}

Pada simulasi ini, dengan menerapkan nilai parameter (12) dan menaikkan jumlah nutrisi yang masuk ke danau sebesar $\kappa_{1,2,3}=0.5$, terjadi peningkatan signifikan pada kepadatan populasi eceng gondok dan penurunan volume danau seperti yang ditunjukkan oleh Gambar 6. Hal ini terjadi karena ketersediaan makanan bagi eceng gondok meningkatkan tingkat pertumbuhannya. Dampak dari eceng gondok dapat dilihat pada volume danau yang ikut menyusut yang diakibatkan oleh naiknya jumlah eceng gondok yang berubah mejadi endapan ketika dia mati.

\section{Revitalisasi dengan Pengerukan Endapan yang ada di Danau}

Untuk membandingkan kondisi danau karena adanya revitalisasi berupa pengerukan, diberikan dua nilai pengerukan yang dilakukan yang ditunjukkan oleh Gambar 4 dan Gambar 7. Jika $\Lambda$ dinaikkan dari 0.1 menjadi 5 , volume pada danau yang awalnya sebesar $v \approx 1.42$ naik menjadi $v \approx 9.8$, meskipun membutuhkan waktu yang lebih panjang dari sebelumnya. Untuk mencapai kondisi yang konstan, volume danau berosilasi terlebih dahulu sampai dengan waktu tertentu. Hal ini menunjukkan bahwa pengerukan terhadap danau yang dilakukan setiap periode waktu tertentu sangat dibutuhkan untuk mempertahankan volume danau.

\section{Kesimpulan}

Pemodelan, analisis, dan simulasi dari revitalisasi danau Limboto dengan pengerukan endapan di danau telah diberikan pada artikel ini. Pemodelan dilakukan secara deterministik, dengan melibatkan faktor-faktor berupa eksistensi dari eceng gondok di danau, adanya endapan dari sungai yang menuju ke danau, dan adanya nutrien yang tersedia di danau. Telah ditunjukkan bahwa dengan adanya pengerukan, volume dari danau dapat dijaga eksistensinya, meskipun terjadi pengurangan volume akibat adanya endapan dan eceng gondok. Hal yang menarik yang bisa dikembangkan lebih lanjut yaitu dengan memasukkan asumsi seperti melakukan pengangkatan secara mekanik terhadap eceng gondok, membatasi limbah rumah tangga yang masuk, menjaga penebangan hutan secara ilegal, dan sebagainya. Dengan intervensi ini, model dapat dieksplorasi lebih lanjut dan dipelajari dinamikanya baik secara lokal maupun global.

\section{Ucapan Terimakasih}

Artikel ini merupakan hasil penelitian yang dibiayai dari dana PNBP Universitas Negeri Gorontalo tahun anggaran 2020 dengan nomor kontrak: B/47/UN47.D1/PT.01.03/2020.

\section{Referensi}

[1] I. Umar, A. Marsoyo, and B. Setiawan, "Analisis Perubahan Penggunaan Lahan Sekitar Danau Limboto Di Kabupaten Gorontalo," Tata Kota dan Daerah, vol. 10, no. 2, pp. 77-90, 2018.

[2] R. Biki, Y. Ismail, Nasruddin, N. G. Rawung, A. A. Katili, S. Suleman, A. M. Ibrahim, Z. R. Faried, A. Moki, Y. Dania, F. S. Nur, Y. Hagu, Y. Dangkua, and A. Olii, Profil Danau Limboto. Gorontalo: BALIRISTI Provinsi Gorontalo, 2009.

[3] KLHRI, Gerakan Penyelamatan Danau (GERMADAN) Danau Limboto. Jakarta: Kementerian Lingkungan Hidup, 2015.

[4] F. Lihawa and M. Mahmud, "Evaluasi Karakteristik Kualitas Air Danau Limboto," Jurnal Pengelolaan Sumberdaya Alam dan Lingkungan (Journal of Natural Resources and Environmental Management), vol. 7, no. 3, pp. 260-266, 2017.

[5] M. T. Fauzi, Murdan, and I. Muthahanas, "Potensi jamur Fusarim SP. sebagai Agen Pengendali Hayati Gulma Eceng Gondok," pp. 64-71, 1995.

[6] D. F. Ilmiawan, Carnawi, D. Anwaristiawan, N. Varantika, R. D. Anisa, and M. Kharis, "Analisis Dinamik Model Predator-Prey pada Penyebaran Grass Carp Fish sebagai Biokontrol Populasi Eceng Gondok di Perairan Rawapening," Journal of Creativity Students, vol. 1, no. 1, pp. 1-7, 2016.

[7] A. Suryandari and Y. Sugianti, "Tumbuhan Air Di Danau Limboto, Gorontalo: Manfaat Dan Permasalahannya," BAWAL Widya Riset Perikanan Tangkap, vol. 2, no. 4, p. 151, 2017.

[8] M. Z. Ndii, Pemodelan Matematika Dinamika Populasi Dan Penyebaran Penyakit Teori, Aplikasi, Dan Numerik. Deepublish, 2018. 
[9] P.-F. Verhulst, “Notice Sur La Loi Que La Population Poursuit Dans Son Accroissement,” Correspondance mathématique et physique, vol. 10, no. 10, pp. 113-121, 1838.

[10] J. D. Murray, Mathematical Biology I: An Introduction, 3rd ed., ser. Interdisciplinary Applied Mathematics, S. Antman, J. Marsden, L. Sirovich, and S. Wiggins, Eds. New York, NY: Springer New York, 2002.

[11] A. A. Berryman, “The Orgins and Evolution of Predator-Prey Theory," Ecology, vol. 73, no. 5, pp. 1530-1535, 1992.

[12] S. Wiggins, Introduction to Applied Nonlinear Dynamical Systems and Chaos, 2nd ed. New York: Springer, 2003.

[13] L. Perko, Differential Equations and Dynamical Systems, 3rd ed. New York: Springer, 2001.

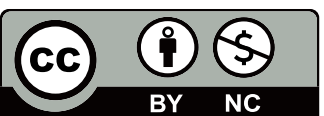

(C) 2020 by the Authors. This article is an open access article distributed under the terms and conditions of the Creative Commons Attribution-NonComercial 4.0 International License. Editorial of JJBM: Department of Mathematics, State University of Gorontalo, Jln. Prof. Dr. Ing. B. J. Habibie, Moutong, Tilongkabila, Kabupaten Bone Bolango, Provinsi Gorontalo 96119, Indonesia. 